\title{
CONSTRUCTION MANAGEMENT AND DESIGN-BUILD: AN OWNER'S EXPERIENCE IN THE PUBLIC SECTOR
}

\author{
DAVID R. Dibner, FAIA*
}

I

\section{INTRODUCTION}

Owners entering into new construction projects are traditionally guided by three major considerations: quality, cost, and time. Decisions concerning construction contracting methods are dominated by these considerations, and the prudent owner frequently evaluates the performance of the contracting methods with reference to them.

Using these three factors as a guide, the General Services Administration (GSA) established a system of construction management along with phased construction in the early 1970's. (Phased construction is a system to speed the completion of a building by allowing design and construction activities to proceed simultaneously.) The catalyst was a GSA study report, Construction Contracting Systems, ${ }^{1}$ which involved a comprehensive survey of construction methods. The report recommended that new methods be adopted by GSA, since the traditional method of contracting for construction, then in use, resulted in completion times for major projects far in excess of schedules achieved in the private sector.

\section{II}

\section{The Construction Management Approach}

Adoption of the construction management approach and the use of phased construction required the overlapping of design and construction activities to permit simultaneous construction of early delivery elements while late delivery elements were still under design. ${ }^{2}$ Separate construction contracts for each major element of work were to be coordinated by the construction manager (CM).

By using the construction management approach, the GSA anticipated dramatic time savings, possibly from one-and-one-half to two years for larger projects. The potential time saving would reduce the total design and construction time by

Copyright $(\mathcal{C} 1983$ by Law \& Contemporary Problems

* Former Assistant Commissioner for Design and Construction, Public Building Service, General Services Administration; now Senior Vice President, Bernard Johnson, Inc., Bethesda, Maryland.

1. Public Building Service, General Services Administration, Construction Contracting Systems: A Report on the Systems Used by PBS and Other Organizations (Mar. 17, 1970).

2. Public Building Service, General Services Administration, The GSa System for ConSTRUCTION MANAGEMENT (rev. ed. 1975) [hereinafter cited as GSA SYSTEM FOR CM]. 
twenty-five to forty percent; but the agency recognized a risk-namely, that interference between work in place and subsequent design requirements was possible. To minimize the risk for the owner, GSA required careful development of bid packages, critical path method analysis, and complete project scheduling by the CM. ${ }^{3}$ The critical path method of scheduling is based upon the development of a network of activities which go into a construction project. Each activity or "event" is listed in the proper time sequence within the building process. For example, painting must follow the installation of plaster, which in turn depends upon the installation of lath which must await the installation of the wall framing. Each event is given a time for accomplishment. The "critical path" through this network is the string of sequential events whose time components are critical to the total time necessary for the entire construction.

With regard to risk on the part of the construction manager who was involved in a contract with GSA, the following position was expressed in the GSA System for Construction Management, " commonly known as "The Plum Book":

One of the major controversies on construction management revolves around the extent of financial risk a Construction Manager should have in the actual construction cost of the building. GSA wants an uninhibited Construction Manager. It is GSA's belief that freeing him of major construction cost risks, [sic] serves the Government's best interest by optimizing the value of his input on the NEW TEAM, since he can now afford to give frank and objective advice, independent of any personal considerations of financial gain or loss in the outcome. ${ }^{5}$

\section{A. The Construction Management Actors}

The system was adopted with enthusiasm coupled with realism. To implement it, a new team approach was established involving the owner or project manager (PM), the CM, and the architect/engineer (A/E), each of whom had specific responsibilities:

1. The Project Manager. A PM assumed responsibility for the owner. The PM was given a charter which delegated to him unprecedented managerial, contractual, budgetary, and administrative authority over a project. He served as liaison between the client and the construction project team and controlled and administered the project resources including personnel, funds, and property. Another responsibility of the PM was preparing and operating a comprehensive project master plan, tailored to a life-cycle plan. ${ }^{6}$ In addition, the PM approved any major revisions in the project schedule and controlled the overall decisionmaking process on the project.

3. Construction Management Control System and other CM requirements, such as the Management Plan for Design and Construction, submission of deliverables, and separate contract planning, are described in id. at 1, 9-12.

4. Id.

5. Id. at 11 .

6. A "life-cycle plan" results from the evaluation of alternative building materials or systems through comparison of the total costs of acquiring, owning, and using the material or system over a specified length of time. 
2. The Construction Manager and the Architect/Engineer. A CM was the prime contractor for professional services. His role was to work with the $P M$ and the $A / E$ from the beginning of design to the completion of construction. The CM furnished the $\mathrm{A} / \mathrm{E}$ with information and recommendations concerning construction technology and market conditions to ensure that the building design stayed within budget. In addition, the CM had control over scheduling of design, management of the procurement effort, the supervision and inspection of the work, and a wide range of other related services as required by his contract. ${ }^{7}$

Selection of a CM involved a two-step procurement process. When a project was identified for construction management in conjunction with phased construction, a CM project notice was published by GSA in the Commerce Business Daily. Interested firms were asked to respond to a detailed questionnaire concerning past experience, personnel, and organizational structure. A GSA evaluation committee rated each firm on the basis of information submitted and other information acquired through independent inquiry into the firm's qualifications. ${ }^{8}$ Prior to the evaluation of submittals the evaluation committee had set up a point system for marking each firm's qualifications. It had also established a cutoff score, and firms scoring above this mark were identified as being within the "competitive range" and therefore eligible for further consideration.

The organizations that were within the "competitive range" were invited to submit price proposals, management plans, and background materials on their key staff. The Public Buildings Service held briefings or orientation sessions for these organizations in preparation for submitting the price proposals.

The contract was awarded to the organization that had the highest total evaluated score. Three factors-qualifications, management plan, and price-had approximately the same weight, but a slightly higher emphasis was placed on the management plan. ${ }^{9}$

The use of the construction management approach necessitated a close working relationship between the architect and the CM. Any differences that surfaced were to be resolved by the PM.

\section{B. Problems With the Construction Management Approach}

With these clearly defined responsibilities in place, GSA entered into a new mode of construction contracting, hoping to achieve the same success that the private sector had experienced. Unfortunately, the government owner had a different experience from that of the private sector owner, primarily because of the rules, regulations, and restrictions that dominate federal procurement.

One major problem that surfaced was that the government owner cannot delegate the same amount of authority that is given to the CM in the private sector. ${ }^{10}$

7. See Public Building Service, General Services Administration, Construction Management Contract 5-7 (rev. ed. Apr. 15, 1975).

8. Nash \& Love, Innovations in Federal Construction Contracting, 45 Geo. WasH. L. REV. 309, 379-80 (1977).

9. GSA SYSTEM FOR CM, supra note 2, at 5.

10. 40 U.S.C. $\S 609$ (c) (1976) provides: 
This lack of authority and divided responsibility prevented effective control and management of the jobsite by the CM.

Another problem was an increased risk of government liability, due to several recent Court of Claims and Board of Contract Appeals decisions holding the government liable for the delays and associated costs caused by its contractors. ${ }^{11}$

A closer examination of the issues of lack of authority and ineffective control and coordination clarifies the government owner's experience with construction management. The CM's lack of authority meant that he could not be held financially responsible for the project and its outcome. This is in contrast to the private sector, where the CM can exercise the full authority of the owner and consequently assume full liability. In other cases, the CM can exercise full project control while guaranteeing a maximum project cost.

The problem of ineffective control and coordination surfaced in phased construction projects which sometimes involved as many as sixteen to twenty-two separate prime contracts. These demanded an inordinate amount of jobsite coordination. Poor coordination resulted in a large number of change orders and costly delays to projects.

GSA experienced this problem in several projects, the costs of which ranged from $\$ 10,000,000$ to $\$ 20,000,000$. In these projects, the contracts with the CM and A/E were awarded at the same time, but none of the projects met with the success that was originally anticipated. The costs, while within the prospectus limitations, far exceeded the initial budget estimates.

Furthermore, the time between the start of construction and substantial completion of the projects was from three-and-one-half to five years, whereas the anticipated completion time for the projects had been from two-and-one-half to three years. Each of the projects had unique situations which contributed to delays and cost increases, but the government saw no evidence that the CM provided any way to reduce the delays or the costs.

All of the projects had similar problems. At the instigation of the new construction management approach by the GSA, the learning curve was long. GSA's staff had to spend a considerable amount of time familiarizing the CMs with government procedures for the administration of contracts.

The contemplated harmony among the team members (the owner, the A/E, and the CM) died upon the signing of the contracts. The CM contract was a fixed

Notwithstanding any other provision of this section the Administrator shall be responsible for all construction authorized by this chapter, including the interpretation of construction contracts, the approval of materials and workmanship supplied pursuant to a construction contract, approval of changes in the construction contract, certification of vouchers for payment due the contractor, and final settlement of the contract.

In private sector construction projects, the powers listed above are often given to the CM, which allows that person to exert the strong authority necessary for the firm direction of the project. In GSA construction contracts, these powers are granted solely to the Administrator of GSA and consequently the CM on the project does not have the power and authority necessary to direct the work.

11. E.g., John A. Johnson \& Sons v. United States, 180 Ct. Cl. 969 (1967); L.L. Hall Constr. Co. v. United States, 379 F.2d 559 (Ct. Cl. 1966); Jacobson \& Co., 80-2 B.C.A. (CCH) ๆ 14,521 (1980); Pierce Assocs., 77-2 B.C.A. (CCH) ๆ 12,746 (1977). These decisions could be interpreted as reflecting a "deep pocket" theory, allowing a recovery by the party least able to bear the cost. 
price contract. Thus, the profit incentive put the CM in an adversary role with the GSA-the CM did the minimum amount to meet contract requirements, while the GSA tried to obtain the maximum amount of services possible.

GSA, the owner, became the mediator of problems among the CM, the A/E, and the construction contractors. After construction began, the separate construction contractors became aware that the CM did not have legal authority over them, and they began to bypass the CM, contacting GSA directly whenever the CM's actions did not suit them. GSA reserved to itself the authority necessary for the direction of the project.

Moreover, it was difficult to enforce CM contract requirements. The nature of the contract was that of management services, such as review of designs, long-lead procurement, separate contracts planning, interfacing, and other services. Unlike the $\mathrm{A} / \mathrm{E}$ contract and the various construction contracts, the CM contract had little hard copy which could be reviewed and accepted or rejected. As a result, once a firm had been awarded the contract, the government had little control over the quality of service provided.

The leading case which increased the risk for the government was Fruehauf Corp. v. United States. ${ }^{12}$ This case was an appeal by plaintiff, Fruehauf Corporation, from a decision by the U.S. Postal Service Board of Contract Appeals. Fruehauf's contract provided for the furnishing and installation of a mechanical mail handling system in a new post office building. The building was to be constructed by another contractor under a completely separate contract. The contract with Fruehauf contained the standard government "suspension of work" clause. ${ }^{13}$ Due to the building contractor's negligence, Fruehauf was delayed approximately fifteen months and incurred substantial delay costs.

The Postal Service Board had denied Fruehauf's claim, primarily on the basis that the delay was in no way attributable to government fault or negligence. ${ }^{14}$ The Court of Claims reversed the Board's decision, holding that the Board had erred as a matter of law in placing on Fruehauf the entire risk of unreasonable delays and substantial inefficiencies directly caused by the government's other contractor on the project. The court referred to its prior decision in Merritt-Chapman $\mathcal{F}^{\circ}$ Scott Corp. $v$. United States, ${ }^{15}$ when it stated that the suspension of work clause may be applicable even when the suspension is not due to the government's fault. An example is when the suspension lasts so long (regardless of the absence of government fault) that the contractor cannot reasonably be expected to bear the risk and costs of the disruption and delay. Relying upon Merritt-Chapman, the court con-

12. 587 F.2d 486 (Ct. Cl. 1978).

13. If . . . the performance of all or any of the work is, for an unreasonable period of time, suspended, delayed or interrupted by an act of the contracting officer in the administration of the contract, or by his failure to act within the time specified in the contract (or if no time is specified, within a reasonable time) an adjustment shall be made . . . for any increase in the [cost of] performance of the contract (excluding profit) necessarily caused by the unreasonable period of such suspension, delay or interruption, and the contract shall be modified accordingly.

Id. at 493 n.3.

14. 73-1 B.C.A. (CCH) I 9897 (1973).

15. 429 F.2d 431 (Ct. Cl. 1970). 
cluded that the fifteen-month delay to Fruehauf was clearly unreasonable and that Fruehauf was therefore entitled to compensation.

The Fruehauf decision implies that in any multiple contractor situation when there is a delay which is not the fault of either the plaintiff or the government and neither party can reasonably be held to have foreseen the delay, the loss to a contractor will be compensated by way of an equitable adjustment under the suspension of work clause. The Fruehauf case illustrates the broad interpretation that is currently being given to the suspension of work clause; namely, a delay of long duration which is for the government's convenience will be compensable to the contractor. ${ }^{16}$ This approach obviously increases the government's exposure to liability for delay claims when phased construction and construction management are utilized.

Another important factor that affected the successful use of construction management in government was the availability of funds. Due to the nature of the funding process, funds were not appropriated in accordance with project schedules. This resulted in delays to certain phases of projects, which led to delay claims. The need for increased resources and the costs of advertising, awarding, and administering multiple contracts, as contrasted with less costly oversight of a single contract, also negated the success of construction management in government.

In sum, the GSA's experience generally showed that the use of CMs involved risks which had severe impacts on project completions and ultimate costs. The method did not yield the same benefits to government that it did to the private sector.

\section{III}

\section{Government ReEvaluation and New Approaches}

The start of the 1980's brought with it a shift in the government's approach concerning the use of construction management. Projects are now competitively bid on a lump-sum basis by general contractors who perform construction work under the supervision of GSA. The project may be divided into the following phases: demolition, foundations, superstructures, and finishes. The phases are run consecutively, not concurrently. This approach simplifies the design and delivery process.

As a responsible owner, GSA continues to evaluate and refine existing approaches, while studying others that promise to save time and money. The concept of project management is being reviewed and tailored to meet today's needs.

Other concepts are being evaluated prior to their initiation in the public sector. One of these is the design-build process. ${ }^{17}$

16. An in-depth review of the cases involving a suspension of work clause appears in 2 R. NASH \& J Cibinic, Federal Procurement Law 1343-56 (3d ed. 1980).

17. Design-build is a process for the delivery of a building whereby the owner contracts with a single entity to provide both the design and construction. This is in contrast to the usual process in which the owner first hires an architect and, once the design is completed, hires a contractor to construct the building 
Recently, the Office of Design and Construction performed an analysis of various alternative design and construction processes in preparation for launching several new construction projects. The analysis was based on certain assumptions related to site acquisition and sufficient market interest. The comparative risk considerations included critical elements such as client satisfaction (responsiveness of the project to the client's requirements), first cost (the initial cost of construction), project delivery time (the time necessary for the completion of design and construction), quality, life-cycle cost, ${ }^{18}$ external coordination (the amount of effort necessary for GSA to coordinate the design and construction), adaptation to requirement change (the ability of delivery process to accept changes during development of the project), potential exposure to claims/litigation, procurement complexity, managerial/administrative complexity, sensitivity to early site selection (impact upon the delivery process if site size and location are determined early in the design phase), risk of (nonsite) schedule delay (impact upon cost of project if time delay occurs), and risk of exceeding the budget.

The processes that were compared included: traditional design/construction (in which construction begins after design is completed); design-build (in which one contact is awarded for both designing and building the project ${ }^{19}$ ), both through advertised selection and negotiated selection; and fast track (compressed schedule in which construction begins while design is being completed). The accompanying Comparative Risk Probability chart is an example of those used in the analysis.

\section{Comparative Risk Probability}

Design-Build

A

Traditional Advertised Negotiated Fast

Critical Elements

Client Satisfaction

First Cost

Project Delivery Time

Quality

Life Cycle Cost

External Coordination

Adaptability to Requirements Change

Claims/Litigation

Procurement Complexity

Managerial/Administrative Complexity

Sensitivity to Early Site Selection

Risk of (Nonsite) Schedule Delay

Risk of Exceeding Budget

4 - Greatest Probability of Success

1 - Lowest Probability of Success

The results of the analysis showed the following benefits in using design-build: potential for time and cost savings, great potential for savings on repetitive-type

18. See supra note 6 .

19. See supra note 17 
structures, and lower management costs after procurement. Based on this analysis, GSA is moving forward with the design-build approach for two border stations.

The design-build process will involve the development of a set of criteria drawings and performance specifications which will define the project requirements. Design-build bidders will be requested to propose a lump-sum cost for delivering the entire project, including a complete set of architectural and engineering drawings and specifications.

The future, then, will provide an opportunity for GSA to continue to evaluate, in practice, the performance of various approaches. The prime considerations for GSA will be those of quality, cost, and time, the traditional triumvirate which dominates design and construction decisionmaking. 